\title{
Biogas Production in Dairy Farming in Indonesia: A Challenge for Sustainability
}

\author{
Jatmiko Wahyudia,b*, Tb. Benito Achmad Kurnanib, Joy Clancyc \\ a Research and Development Office, Pati Regency, Jalan Sudirman No. 26 Pati, Central Java 59113, Indonesia \\ b Graduate Program of Environmental Science, Universitas Padjadjaran, Jalan Sekeloa Selatan I Bandung 40132, Indonesia \\ c Twente Centre for Studies in Technology and Sustainable Development-CSTM, University of Twente, PO Box 217, 7500 AE, Enschede, The \\ Netherlands
}

\begin{abstract}
Biogas plays an important role in supporting and ensuring the dairy farming sector remains sustainable. Biogas technology is not only as a method to dispose dairy farming waste but also benefiting economically, socially and environmentally. Biogas technology has been introduced since 1970s and many biogas programmes have been implemented in Indonesia. However compare to other countries like China and India, the dissemination of biogas technology in Indonesia runs quite slowly. There are several factors such as financial, policies and people's perception hindering biogas use regarding the increase of biogas plants installed in Indonesia. In addition, many installed biogas plants are non-functional due to inadequate maintenance causing users stop to operate biogas plants and influencing potential users to reject adopting the technology. This paper provides an overview of biogas production sustainability which consists of five sustainability dimensions: technical, economic, social, environmental and organizational/institutional sustainability. Understanding the biogas sustainability helps stakeholders to realize that in order to promote biogas technology many sectors must be developed and many institutions must be involved and cooperated. The sustainability of biogas will determine the success of biogas dissemination particularly in dairy farming in the future.
\end{abstract}

Keywords: biogas, dairy farming, sustainability

Article History: Received June 19, 2015; Received in revised form August 26, 2015; Accepted October 14, 2015; Available online

How to Cite This Article: Wahyudi, J., Kurnani, T.B.A., Clancy, J. (2015). Biogas Production in Dairy Farming in Indonesia: A Challenge for Sustainability. Int. Journal of Renewable Energy Development ,4(3), 219-226.

http://dx.doi.org/10.14710/ijred.4.3.219-226

\section{Introduction}

The dairy farming sector in Indonesia shows a good trend indicated by an increase in the dairy cattle population with average growth $10.74 \%$ during the period 2008-2012 (BPS2014). The majority of dairy farming is small scale farming which has an average three to five cows per farm and owned by individual farmers (IFC 2011).

Indonesia, a country with 248.8 million population and population growth $1.37 \%$ in 2013 , still imports $70 \%$ of bulk dairy demand (BPS 2014; Bahri 2008). Hence, Indonesia is a big and attractive market for milk businesses and there are many opportunities in future to develop the dairy farming sector in this country. Therefore the Indonesian government strongly supports the development of dairy industries and has a target to achieve self-sufficiency in milk production by 2020 (Herawati \& Priyanto 2013).
However the willingness of the Indonesian government to develop dairy farming faces many barriers. One of the problems in dairy farming is related to waste management. Waste from dairy cows' excretion becomes big problem due to the quantity and quality faeces and urine produced (The Japan Institute of Energy 2008). A study about waste management in small scale dairy farming in West Java, Indonesia showed that farmers dump big portion of faeces and urine from their dairy farms to the river (Table 1).

Anaerobic digestion (AD) has the potential for waste management in dairy farming with useful by-products and providing an environmentally sustainable energy. Biogas is produced through $\mathrm{AD}$ that is the process for the treatment of organic materials like manure in the absence of oxygen (Wilkinson 2011). China and India are leading countries in domestic biogas production in the World. By 2010, China and India installed about 40 million and 4.5 million domestic biogas plants, respectively (SNV 2011). 
Citation: Wahyudi,J., Kurnani, T.B.A. \& Clancy,J.(2015) Biogas Production in Dairy Farming in Indonesia: A Challenge for Sustainability. Int. Journal of Renewable Energy Development, 4(3),219-226, http://dx.doi.org/10.14710/ijred.4.3.219-226

$\mathrm{P}$ a g e $\mid 220$

Table 1

Dairy wastes handling in the Upper Citarum Watershed, West Java, Indonesia

\begin{tabular}{lcccc}
\hline \multirow{2}{*}{ Handling } & \multicolumn{3}{c}{ Type of Waste (\%) } \\
\cline { 2 - 5 } & Faeces & Urine & Forage refusal & Concentrate \\
\hline Dump to the river & 30.0 & 95.0 & 18.8 & 7.5 \\
Larger portion for compost making & 42.5 & 2.5 & 40.0 & 8.8 \\
Smaller portion for compost making & 7.5 & 1.3 & 8.8 & 1.3 \\
Used directly as organic fertilizer & 10.0 & 1.3 & 3.8 & 0.0 \\
Sold to others & 8.8 & 0.0 & 0.0 & 0.0 \\
Burnt & 1.3 & 0.0 & 0.0 & 0.0 \\
No left over & n.a. & n.a. & 21.3 & 82.5 \\
Total & 100.0 & 100.0 & 100.0 & 100.0 \\
\hline
\end{tabular}

(Parikesit et al. 2005); n.a.: not applicable

The dissemination of biogas is believed having contributions to sustainable development particularly on millennium development goals (MDGs) but the extent of biogas has correlation to sustainable development not clear enough (Gosens et al. 2013). The objective of this paper is to provide an overview of biogas production sustainability particularly in dairy farming in Indonesia by identifying and explaining sustainability indicators. The sustainability of biogas plants operations and programmes from other countries is necessary provided to compare that of in Indonesia.

The paper is organised as follows: Section 1 provides the importance of the study as introduction. Section 2 presents the overview of biogas technology including properties of biogas, factors that influencing of anaerobic digestion performance, and bio digesters type. Section 3 reviews five dimensions of sustainability including the indicators; and finally, section 4 contains conclusion of the paper.

\section{Review on biogas technology}

In this section, we only review about the technology which has close correlation with the sustainability. For instance, type of biogas plants that commonly used by dairy farmers is necessary reviewed because it has close correlation with economic sustainability. Therefore, there are no in-depth discussion about bio-chemical process and conversion of organic waste into biogas.

\subsection{Properties of Biogas}

Biogas is mainly composed of methane, a combustible gas, and carbon dioxide (Table 2). Due to containing incombustible material like carbon dioxide, the caloric value of biogas (produced from manure) is lower than pure methane that are around 4800-6700 $\mathrm{kCal} / \mathrm{m}^{3}$ and $8900 \mathrm{kCal} / \mathrm{m}^{3}$, respectively (Widodo \& Hendriadi 2005).

The energy content of biogas is higher than energy content of traditional biomass such as fuel wood, charcoal and cow dung (Lam \& Heegde 2011). Energy content of biogas is lower compare to fossil fuel but biogas is cleaner and more sustainable. Due to its characteristic, biogas is an excellent substitute to fossil fuels and biomass fuels for electricity generation, cooking and heating (Massé et al. 2011).

Table 2

Composition of biogas

\begin{tabular}{lcc}
\hline Compound & Chemical symbol & Content (\%Vol) \\
\hline Methane & $\mathrm{CH}_{4}$ & $50-75$ \\
Carbon dioxide & $\mathrm{CO}_{2}$ & $25-45$ \\
Water vapour & $\mathrm{H}_{2} \mathrm{O}$ & $2\left(20^{\circ} \mathrm{C}\right)$ \\
Oxygen & $\mathrm{O}_{2}$ & $<2$ \\
Nitrogen & $\mathrm{N}_{2}$ & $<2$ \\
Ammonia & $\mathrm{NH}_{3}$ & $<1$ \\
Hydrogen & $\mathrm{H}_{2}$ & $<1$ \\
Hydrogen sulphide & $\mathrm{H}_{2} \mathrm{~S}$ & $<1$
\end{tabular}

(Al Seadi et al. 2008)

\subsection{Influencing factors of $\mathrm{AD}$}

The composition and the yield of biogas differ to some degree depending on many factors. Some factors relate to management in $\mathrm{AD}$ operation such as type of substrates, $\mathrm{pH}$ and substrate preparation while other factors relates to construction quality and design of reactor (digester) like hydraulic retention time (HRT) and gas tightness. However, factors related to construction and design of reactor do not become main attention because the construction and design of digester for digesting substrate from dairy farming and other sources are relatively same.

In the dairy production system, biogas technology can be used both for digesting manure or co-digesting manure with other organic materials that are available in dairy farms (El-Mashad \& Zhang 2010). The literature shows that co-digestion of dairy cow manure and switch grass (Zheng et al. 2015), cocoa shell (Rico et al. 2014), cotton gin waste and organic fraction of municipal solid waste (Macias-Corral et al. 2008) and food waste (El-Mashad \& Zhang 2010) improve the biogas yields.

The presence of inhibitor like oxygen and toxic materials gives significant adverse impacts on biogas production (Clemens et al. 2006; Frac \& Ziemiñski 2012). Oxygen initiates an alternative decomposition which does not produce a combustible gas. The use of detergent for cleaning stable and medicine for cows has to be managed properly. Toxic materials, for instance detergents, will inhibit the metabolism and growth of microorganisms results in reduced biogas production. 
In an anaerobic digestion, many different species of microorganisms work together performing very complex biological and biochemical process to form biogas (Schnürer \& Jarvis 2010).

\subsection{Type of biogas plants}

Commonly, there are three types of material that used for making biogas digester in Indonesia: plastic tubular, fibreglass, and concrete (fixed dome). The benefits and disbenefits of each type of digester are showed in Table 3.

\section{Selection of Sustainability Indicators}

This section reviews on sustainability dimension of biogas production particularly in dairy farming. The term sustainability in this paper refers to the definition of sustainable development in the Brundtland Report. Sustainability defined as "development that meets the needs of the present without compromising the ability of future generations to meet their own needs" (Ilskog 2008).

International organization like United Nation (United Nations 2007) suggested lists of sustainability indicators. However in some cases, the indicators are very general and not relevance for local case. Therefore in this paper we try to identify the indicators that derived from five dimensions of sustainability proposed by Ilskog (Ilskog 2008). The sustainability dimensions consist of technical, economical, social/ethical, environmental and institutional sustainability.

\subsection{Technical Sustainability}

Technical sustainability refers to sustainability of material and support service that ensure the operation of biogas plants running well and not face major problems.

\subsubsection{Feedstock Availability}

Table 3

The benefits and disbenefits of different types of biogas digester

\begin{tabular}{|c|c|c|c|}
\hline & Concrete (Fixed dome) & Fibre glass & Balloon \\
\hline Benefits & $\begin{array}{l}\text { Low initial costs and long useful life- } \\
\text { span; no moving or rusting parts } \\
\text { involved; basic design is compact, } \\
\text { saves space and is well insulated; } \\
\text { construction } \\
\text { employment. }\end{array}$ & $\begin{array}{l}\text { Permanent quality control at the } \\
\text { factory; good air tightness and long } \\
\text { service life; good insulation effect; } \\
\text { light and easily transported; short } \\
\text { construction periods. }\end{array}$ & $\begin{array}{l}\text { Low cost, ease of transportation, low } \\
\text { construction sophistication, high } \\
\text { digester temperatures, uncomplicated } \\
\text { cleaning, emptying and maintenance; } \\
\text { short construction periods. }\end{array}$ \\
\hline Disbenefits & $\begin{array}{l}\text { The frequent problems with the gas- } \\
\text { tightness; The gas pressure fluctuates } \\
\text { substantially relying on the volume of } \\
\text { the stored gas; long construction } \\
\text { periods. }\end{array}$ & $\begin{array}{l}\text { High cost of raw materials and } \\
\text { fluctuations in prices; floating where } \\
\text { high underground water level } \\
\text { persists. }\end{array}$ & $\begin{array}{l}\text { The relatively short live spans, high } \\
\text { susceptibility to damage, little } \\
\text { creation of local employment; and } \\
\text { inconvenient feeding and discharge }\end{array}$ \\
\hline
\end{tabular}

(Cheng et al. 2013)(Kossmann et al.)

Generally, the decrease of water addition ratio will decrease the production of biogas (Putri, Saputro, \&
In general, manure and water are needed as feedstock to operate biogas plants especially in dairy farming. Therefore, the amount of available manure and water must be enough to feed and match the digester size.

Manure, a mix of faeces and urine, from dairy cows has a potential as a feedstock of biogas due to its quantity (Table 4) and properties like volatile solid content (Moody et al.2011).

Table 4

The standard of dairy cows excretion

\begin{tabular}{lcc} 
Classification & \multicolumn{2}{c}{$\begin{array}{c}\text { Amount } \\
\text { (kg/ head/day) }\end{array}$} \\
& Faeces & Urine \\
\hline Lactating cows & 45,5 & 13,4 \\
Non lactating cows & 29,7 & 6,1 \\
Heifer & 17,9 & 6,7 \\
(The Japan Institute of Energy 2008) & &
\end{tabular}

The number of dairy cattle in certain area can be used to predict the potential of manure produced and biogas technology developed. About $98 \%$ of dairy cows population in Indonesia are concentrated in Java Island, the most populated island in Indonesia, spreading in East Java (Jawa Timur) province $50.45 \%$, Central Java (Jawa Tengah) province $25.23 \%$ and West Java (Jawa Barat) province $22.23 \%$ (BPS 2014). Surprisingly, about $57 \%$ of dairy cows population was located in only five regencies as follows: Malang and Pasuruan in East Java, Boyolali and Semarang in Central Java and Bandung/West Bandung in West Java (IFC 2011).

The second important feedstock to run biogas plants is water. Water availability plays two important roles to ensure anaerobic digestion running well. First, the first stage of anaerobic digestion is hydrolysis which the water is needed to decompose complex organic matter such as polysaccharide, protein and lipid into smaller units such as monosaccharide, amino acids and volatile fatty acids. Second, water has to be added into manure to prevent manure too thick by maintaining total solid (TS) content of the dilution from 7 to 10 percent. 
Citation: Wahyudi,J., Kurnani, T.B.A. \& Clancy,J.(2015) Biogas Production in Dairy Farming in Indonesia: A Challenge for Sustainability. Int. Journal of Renewable Energy Development, 4(3),219-226, http://dx.doi.org/10.14710/ijred.4.3.219-226

$\mathrm{P}$ a g e $\mid 222$

of benefits developing biogas in dairy farming is dairy farming consuming lots of water for both drinking and cleaning the cows and stall. Farmers can use the cleaning water as a biogas feedstock. Cleaning is very important in dairy farm activity to prevent contamination of milk and to reduce risk of cow's diseases like mastitis.

\subsubsection{Support services availability}

One of problems regarding sustainability of biogas in Indonesian is that biogas programme from the government does not cover the development of supporting industries (SNV 2011). Business sectors which supply fabricated biogas digesters (fibre glass and plastic digesters), spare parts, appliances, masons etc, are needed to support biogas sustainability.

In developing countries, about $50 \%$ of biogas plants are non-functional due to lack of maintenance and repair of existing facilities (Bond \& Templeton 2011). An (1997) stated that one of the main factors causing the low acceptance of concrete (fixed dome) digester that difficulties in obtaining spare parts for replacement.

Most of traditional dairy farmers in Indonesia live in rural areas and find difficulties to access repair facilities and shops selling spare part where generally located in cities. Without repair facilities or spare part shops nearby, it will be time-consuming and increase the cost. Hence, future of biogas technology depends on developing adequate servicing networks (Bhattacharyya 2012).

\subsection{Economic Sustainability}

Economic sustainability in this paper more focuses on a macro-economic point of view rather than microeconomic point of view (financial analysis). Macroeconomic considers externalities due to project execution and has broader scope than financial analysis (e.g. net present value, simple pay-back period, internal rate of return)(Chakrabarty et al. 2013). However, short description about financial analysis of biogas investment in Indonesia is showed to understand the reason why financial support is needed.

\subsubsection{Financial support}

Since cost of biogas constructions is unaffordable for traditional dairy farmers, lack of funding becomes main reason for potential biogas users to reject adopting biogas (Listyawati, Meidiana, \& Anggraeni 2014). Without considering the interest of investment, the simple pay-back period of biogas investment in Indonesia is 4-6 years (Widodoet al. 2009; Rosyidi et al. 2014) or even the investment is not able to meet economic feasibility (Budiarto et al. 2013).

Without financial support, it is hard for traditional dairy farmers to finance their plants by their own money. Not surprisingly, the majority of biogas installation in Indonesia is partially or fully funded by the Indonesian government or other organizations such as banks, dairy companies and cooperatives. Sun et al.(2014) revealed the number of domestic biogas digesters in China increasing dramatically due to the subsidy program,

The Indonesian government, both national and local government, generally provides financial support in two ways, grant (direct and indirect) and loan. The government (mainly local government) gives grant directly (without intermediary organization) to farmers for building biogas plants. The government also provides indirect grant through some organizations like Hivos to run biogas programmes including biogas construction and training.

Since 2000, the Indonesian government has been launching low interest loan called loan for food and energy security through some national banks and people can use the loans for building biogas. However, it is not easy for farmers to access the loan due to lack of promotion, complicated procedures, and limited collateral ownership (Sayaka \& Rivai 2011).

\subsubsection{Contribution to income generation}

Study in Tanzania shows that average annual farm income for households who adopt biogas is significantly higher than the income for non-adopters (Laramee \& Davis 2013). Biogas adopters can sell their biogas and slurry, a by-product of biogas plant, as organic fertilizer to increase their income generation (Nurmalina \& Riesti 2010; Sharma \& Nema 2013). In Pati regency, Central Java, the owner of $18 \mathrm{~m}^{3}$ biogas installation provides biogas for 5 customers and get about IDR 15,000 (US\$ 1.2) per month per customer (household) or IDR 75,000 (US\$ 6) per month in total (Wahyudi 2013).

However, the problem is that the price of biogas and fertilizer cannot follow the price of other energy carriers. The price of biogas is same for every customer eventhough the customers who have different family size consume different amount of biogas. The price of biogas usually cheaper than the price of LPG (liquefied petroleum gas) and the price nearly increases eventhough the price of LPG always grows. LPG becomes a main source for domestic cooking in Indonesia after the introduction of LPG in 2007. On the one hand, it is good for customers because they spend less money. On the other hand, it is not good because the biogas owner receive less revenue.

\subsubsection{Reducing household expense}

Farmers who adopt biogas can also save their money by using slurry for fertilizer in their own fields and by using biogas for cooking, lighting and electricity (Purwono, Suyanta, \& Rahbini 2013; Widyastuti, Purwanto, \& Hadiyanto 2013). Biogas is a good option for substituting LPG as the main source of cooking energy in areas where people install biogas indicated by the substantially lower LPG consumption rate (Bedi et al. 2012). 
Studies in dairy farms in Haurngombong village, Sumedang, West Java, show that a five-member family of biogas user savedIDR75,000 (US\$ 6) per month for substituting LPG (Alamsyah \& Hermawati 2011). Moreover, people in the village also reduced their electricity bill since the biogas also used for supplying electricity for 40 households for 3 hours (18.00-21.00) (Hartiningsih \& Setiawan 2011).

Another survey was conducted to 157 biogas households in 9 provinces in Indonesia showing the result that after using biogas, the biogas users can save per month up to IDR 158,981 (US\$ 12), IDR 40,152 (US\$ 3 ) and IDR 43,615 (US\$ 3.3) from kerosene, LPG and firewood purchase, respectively (Hivos 2014a).

\subsubsection{Contribution to employment generation}

Adoption of biogas also has the potential to create employment in the district and countrywide (Mwakaje 2008). Chakrabarty et al. (2013) revealed that biogas plants create two types of employment or job opportunities: organizational employment and household-based employment. The development of biogas sector in Indonesia encourages the creation of jobs and new biogas business sectors (contractors, masons, training institutions, input suppliers). In Indonesia, it will be predicted 1,000 jobs created by 2016 due to the activity of Hivos in biogas business (Hivos 2014b).

Moreover, by installing biogas enables household to create job opportunities. Household can create productive works such as gardening, fishing and culinary businesss because biogas provide good quality energy and offers more spare time for family members so that they can use the time to run business.

\subsection{Social Sustainability}

\subsubsection{Contribution to human health}

Dairy cows' excretion contains hazardous material like pathogenic bacteria and causes problems in sanitation and human health (Avery et al. 2014; Prasetyo \& Herawati 2011). The waste can contaminate ground and river water and creates problems on human health since most of people in Indonesia use the water for drinking and washing. Due to the water and odour pollutions, dairy farming activities often raises complaints from their neighbours since most of the dairy farming in Indonesia is situated in densely populated areas.

Utilizing biogas improves human health and sanitation (Chand et al. 2012; Massé et al. 2011). AD can reduce a diverse range of pathogens contained in livestock manure that can lead to disease (Avery et al. 2014) and offers significant reduction of odoriferous substances (Al Seadi et al. 2008). Cooking by using biogas can mitigate indoor air pollution causing eye infections and respiratory problems due to burning firewood or other biomass.

\subsubsection{Contribution to promote gender equality}

The term "gender" not only refers to the biological differences, but more emphasis on the social roles performed by women and men (Clancy \& Roehr 2003). In gender point of view, expanding energy access through technology intervention has connections with easing the burdens of women, increasing leisure activities, improving health, education, access to information and community involvement (Oparaocha \& Dutta 2011).

In traditional dairy farmer's households, women have responsibility in cooking activities including cleaning utensils and providing fuel for cooking while men have responsibility to manage farm including operating biogas installation. The literature reveal that the installation of biogas plants at the household offers women more advantages compared to men and provides better opportunities for gender equality in rural areas (Kabir et al. 2013; Surendra et al. 2014)

In areas where people use fuel wood for cooking, using clean energy like biogas reduces the risk of women and child exposed to indoor smoke pollution and prevents them from possibly getting respiratory diseases (Ding et al. 2014). Biogas reduces women's labour intensity for cleaning utensils and collecting fuel wood so that it offers more spare time and women can use the time for education activities and participation in public activities (Lam \& Heegde 2011; Ding et al. 2014). One concern when using LPG in Indonesia is the frequent accidents on the use of LPG that reported by mass media causing many people feels insecure using LPG (Budya \& Arofat 2011). Compared to LPG, biogas is more secure for women working in the kitchen because of its properties and safety system.

\subsection{Environmental Sustainability}

Environmentally, biogas contributes to GHG emissions reduction by substituting dirtier energy carriers, substituting chemical fertilizer and changing waste management (Clemens et al. 2006). Biogas is a renewable energy source to substitute and to reduce fossil fuel and biomass use. Substitution of kerosene, fuel wood and cattle dung cake with biogas as fuel for cooking reduced GHG emission (Pathak et al. 2009).

Slurry contains nutrients such as nitrogen, phosphorus, and other minerals so that it can replace and reduce the usage of chemical fertilizer (Marañón et al. 2011). The GHG emission due to fossil fuel combustion for the chemical synthesis of nitrogen fertilizers is around 1\% of total anthropogenic GHG emissions (Scialabba \& Muller-Lindenlauf 2010).

Globally, the dairy sector contributes $4 \%$ of the total global anthropogenic GHG emissions (FAO 2010). Methane $\left(\mathrm{CH}_{4}\right)$ and nitrous oxide $\left(\mathrm{N}_{2} \mathrm{O}\right)$ are the most important GHG emitted from dairy farming due to their percentage and global warming potential (GWP). Over $50 \%$ of total GHG emissions from the dairy sector is contributed by $\mathrm{CH}_{4}$ and followed by $\mathrm{N}_{2} \mathrm{O}$ which 
Citation: Wahyudi,J., Kurnani, T.B.A. \& Clancy,J.(2015) Biogas Production in Dairy Farming in Indonesia: A Challenge for Sustainability. Int. Journal of Renewable Energy Development, 4(3),219-226, http://dx.doi.org/10.14710/ijred.4.3.219-226

P a g e $\mid 224$

contributes to between $30-40 \%$ of total emissions (FAO 2010). Methane and nitrous oxide have GWP 25 and 298 times higher than $\mathrm{CO}_{2}$, respectively.

$\mathrm{CH}_{4}$ emission from manure management is mainly generated during manure storage. Amon et al.(2006) studied the reduction of GHG emissions in five differently treated (no treatment; slurry separation; AD; slurry aeration and straw cover) of dairy cattle manure. The study revealed that $\mathrm{AD}$ was the best way to reduce GHG emissions compared to other options. AD provides also controlled $\mathrm{CH}_{4}$ emission during storage and by burning $\mathrm{CH}_{4}$; it will be converted into $\mathrm{CO}_{2}$ that has a less GWP compared to $\mathrm{CH}_{4}$.

Direct $\mathrm{N}_{2} \mathrm{O}$ emissions occur due to the activity of microorganism utilizing nitrogen in manure through nitrification and denitrification processes while indirect $\mathrm{N}_{2}$ Oemissions from manure occur from leaching, runoff and volatilisation of nitrogen (Cornejo \& Wilkie, 2010). $\mathrm{AD}$ reduces carbon and dry matter content of manure which reduces $\mathrm{NH}_{3}$ emissions after slurry application as fertilizer and prevents microorganism to form $\mathrm{N}_{2} \mathrm{O}$ during manure storage (Amonet al. 2006; Schnürer \& Jarvis 2010).

\subsection{Institutional Sustainability}

\subsubsection{Stakeholder participation}

Stakeholder is defined as actors or institutions that involve and support biogas development spreading in national, provincial and local levels. Support can be given in the form of policy, financial and technical supports and every actor/institution can play in one or multiple roles. The development of biogas was highly affected by national policy, but capability of local actors determined the sustainability of biogas development (Fallde \& Eklund 2014).

Government institutions are the main actor for developing renewable energy including biogas in Indonesia. Many government institutions in the national level involve in renewable energy sector, whereas The Directorate General of New and Renewable Energy, under Ministry of Energy and Mineral Resources (MEMR), is the main actor for new and renewable energy development in Indonesia.

Since the Indonesia government implemented a decentralization policy in 2004 , local government plays very an important role in implementing policies in all sectors. According to Indonesian energy law number 30, year 2007, along with vertical institutions (national and provincial level), the local government has roles in energy sector including planning and policy implementation. Political factors (e.g. complex corruption, decentralization, lack of coordination) have been becoming main obstacle of renewable energy support in Indonesia since many horizontally and vertically institutions involve and play in different roles in the sector (Marquardt 2014).
Both national and international non-governmental organizations (NGO) contribute mainly in technical and capacity building aspects of biogas development. Local NGO like LPTP (Institute for Rural Technology Development) and SLI (Indonesian Land Care) together with international organizations run biogas programme in many parts of Indonesia. Hivos with assistance from SNV, a Dutch non-profit organisation, has built more than 11,000 units of small-scale biogas digesters in nine provinces of Indonesia during the period 20092013(Hivos 2014a).

Nestle, a dairy company, together with its partners contributes in biogas sector by providing loan without interest for building biogas and disseminating the technology in its milk procurement area in East Java (SNV 2011; Bedi et al. 2012). Alamsyah \& Hermawati, (2011) revealed that some stakeholders namely PLN (Indonesia's national electricity company), the academe and dairy cooperatives gave significant contribution for developing biogas in Haurngombong village, West Java. PLN provided technological assistance to convert biogas into electricity, the academe contributed in technical assistance and knowledge development, and dairy cooperatives contributed in funding assistance.

Even though many institutions contribute in $\mathrm{RE}$ sector including biogas, the development of RE sector in Indonesia shows lower achievement compared to India. Singh \& Setiawan (2013) found three institutional problems in RE sector in Indonesia: 1) no dedicated institutions dealing with the RE sector at the ministerial level, 2) no financial institution dedicated to funding the development, 3) no dedicated institution focusing on human resource and knowledge development. There is no institution having data regarding the number of digester installed in Indonesia year by year so that quite difficult to evaluate the development of biogas in Indonesia.

\subsubsection{Capacity Building}

Capacity building programme aims to develop the capacity of existing organizations and institutions and to facilitate establishment of organizations and institutions for sustainability of the biogas sector (Hivos, 2014a). Allocating adequate funding for capacity building program is one of key success of the government of China to promote biogas dissemination (Sun et al. 2014).

Most of biogas programmes in Indonesia which are run both under government and non government organization programmes only focus on introducing biogas as alternative energy by building biogas installations without considering building capacity of users and masons prior to install the biogas digester. The success of the implementation generally is measured mainly from the number of biogas installed while monitoring and evaluation of the effectiveness and continuity of biogas operations are not main concern. 
Capacity building and community assistance in terms of transferring the knowledge provide positive impact in sustainability biogas operations, particularly in rural areas (Rosyidia et al. 2014; Herdiawan, Kurnami, \& Astuti 2014). Normal functioning of biogas plants relies $30 \%$ on construction quality, but $70 \%$ on post-installation management (SNV 2011). Training for mason aims to prevent design and construction fault resulting in low performance of biogas digester. Meanwhile, training for biogas users where generally live in rural areas purposes to make sure the users can operate and manage biogas plant well.

Even though the application of biogas technology in Indonesia faces several technical barriers such as malfunction of the reactor, non-user friendly design and manually handling (Widodo et al. 2009), actually institutional aspect is the main barrier to proliferate the implementation of biogas in Indonesia. Most of technical barriers can be overcome by strengthening capacity of actors who involve in technical sector.

\section{Conclusion}

Indonesia has abundant potential to develop biogas technology in dairy farming and the potential will be predicted increase since the development of dairy farming sector in Indonesia also shows a good trend. However, the development of biogas in Indonesia does not considers many indicators of sustainability (e.g. supporting services availability, capacity building, political factors) resulting in slower development compared to some Asian countries.

About $67 \%$ of poor people in Indonesia live in rural areas and have occupation in agriculture sector including livestock sector (Swastika 2011). Biogas technology has not only potentials to tackle the negative impact of livestock waste but also to alleviate poverty by supporting agriculture including livestock sector, providing clean energy, improving human health. The success of biogas dissemination in Indonesia will give significant contribution to development of rural areas where most of dairy farming located.

\section{Acknowledgments}

We would like to thank to Pusbindiklatren Bappenas (Planning, Training, and Educational Development Centre of the Indonesian National Planning Board) and Nuffic Neso for funding this research.

\section{References}

Alamsyah, P., \& Hermawati, W. (2011). Kajian Pola Pembiayaan Biogas dalam Mendukung Pembangunan Desa Mandiri Energi, Studi Kasus : Desa Haurngombong, Sumedang.Prosiding Seminar Nasional Peran Jejaring Dalam Meningkatkan Inovasi dan Daya Saing Bisnis.
Al Seadi, T., Rutz, D., Prassl, H., Köttner, M., Finsterwalder, T., Volk, S., et al. (2008). Biogas Handbook. Esbjerg University of Southern Denmark.

Amon, B., Kryvoruchko, V., Amon, T., \& Zechmeister-Boltenstern, S. (2006). Methane, nitrous oxide and ammonia emissions during storage and after application of dairy cattle slurry and influence of slurry treatment. Agriculture, Ecosystems and Environment, 112, 153-162.

An, B. X. (1997). The Role of Low-cost Plastic Tube Biodigesters in Integrated Farming Systems in Vietnam. Proceeding of Second FAO Electronic Conference on Tropical Feeds (pp. 277-294).

Avery, L. M., Anchang, K. Y., Tumwesige, V., Strachan, N., \& Goude, P. J. (2014). Potential for Pathogen reduction in anaerobic digestion and biogas generation in Sub-Saharan Africa. Biomass and Bioenergy, 70, 112-124.

Bahri, S. (2008). Strategy and Programmes of Livestock Development in Indonesia. Prosiding Seminar Nasional Teknologi Peternakan dan Veteriner 2008 (pp. 4-14).

Bedi, Arjun; Benscha, Gunther ; Niemanna, Rebecca ; Peters, Jörg; Sparrow, Robert ; Tasciotti, Luca. (2012). Impact Evaluation of the Indonesia Domestic Biogas Programme. Rheinisch-Westfälisches Institut für Wirtschaftsforschung, Essen, German and International Institute of Social Studies, Erasmus University, Rotterdam, The Netherlands.

Bhattacharyya, S. C. (2012). Energy access programmes and sustainable development: A critical review and analysis. Energy for Sustainable Development, 16, 260-271.

Bond, T., \& Templeton, M. R. (2011). History and Future of Domestic Biogas Plants in the Developing World. Energy for Sustainable Development, $15,347-354$.

BPS. (2014). Statistical Yearbook of Indonesia 2014. Jakarta

Budiarto, R., Ridwan, M. K., Haryoko, A., Anwar, Y. S., Suhono, \& Suryopratomo, K. (2013). Sustainability challenge for small scale renewable energy use in Yogyakarta. Procedia Environmental Science, 17, $513-518$.

Budya, H., \& Arofat, M. Y. (2011). Providing cleaner energy access in Indonesia through the mega project of kerosene conversion to LPG. Energy Policy, 39, 7575-7586.

Chakrabarty, S., Boksh, F. M., \& Chakraborty, A. (2013). Economic viability of biogas and green self-employment opportunities. Renewable and Sustainable Energy Reviews, 28, 757-766.

Chand, M. B., Upadhyay, B. P., \& Maskey, R. (2012). Biogas Option for Mitigating and Adaptation of Climate Change. Proceeding of Rentech Symposium Compendium, (pp. 5-9).

Cheng, S., Li, Z., Mang, H.-P., \& Huba, E.-M. (2013). A review of prefabricated biogas digesters in China. Renewable and Sustainable Energy Reviews $28,738-748$.

Clancy, J., \& Roehr, U. (2003). Gender and energy: is there a Northern perspective?. Energy for Sustainable Development, 7(3), 44-49.

Clemens, J., Trimborn, M., Weiland, P., \& Amon, B. (2006). Mitigation of Greenhouse Gas Emissions by Anaerobic Digestion of Cattle Slurry. Agriculture, Ecosystems and Environment, 112, 171-177.

Cornejo, C., \& Wilkie, A. C. (2010). Greenhouse gas emissions and biogas potential from livestock in Ecuador. Energy for Sustainable Development, 14, 256-266.

Ding, W., Wang, L., Chen, B., Xu, L., \& Li, H. (2014). Impacts of renewable energy on gender in rural communities of north-west China. Renewable Energy, 69, 180-189.

El-Mashad, H. M., \& Zhang, R. (2010). Biogas production from codigestion of dairy manure and food waste. Bioresource Technology, 101, 4021-4028.

Fallde, M., \& Eklund, M. (2014). Towards a sustainable socio-technical system of biogas for transport: the case of the city of Linkoping in Sweden.Journal of Cleaner Production. 1-12

FAO. 2010. Greenhouse Gas Emissions from the Dairy Sector: A Life Cycle Assessment. Food and Agriculture Organization of the United Nations, Rome, Italy.

Frac, M., \& Ziemiñski, K. (2012). Methane fermentation process for utilization of organic waste. International agrophysics, 26, 317330.

Gosens, J., Yonglong, L., Guizhen, H., Bluemling, B., \& Beckers, T. A. (2013). Sustainability effects of household-scale biogas in rural China. Energy Policy, 54, 273-287. 
Citation: Wahyudi,J., Kurnani, T.B.A. \& Clancy,J.(2015) Biogas Production in Dairy Farming in Indonesia: A Challenge for Sustainability. Int. Journal of Renewable Energy Development, 4(3),219-226, http://dx.doi.org/10.14710/ijred.4.3.219-226

$\mathrm{P}$ a g e $\mid 226$

Hartiningsih \& Setiawan, (2011). Pengaruh modal sosial dalam membangun kemandirian desa mandiri energi. ProsidingSeminar Nasional Peran Jejaring Dalam Meningkatkan Inovasi dan Daya Saing Bisnis.

Herawati, T., \& Priyanto, D. (2013). Performance of Dairy Processing Industry in Supporting Self-Sufficiency of Milk in Indonesia). ProsidingSeminar Nasional Teknologi Peternakan dan Veteriner 2013 (pp. 234-249).

Herdiawan, G., Kurnami, T. A., \& Astuti, Y. (2014). Discontinuance Application of Innovation Biogas By Dairy Farmer (Case Study in Pagerageung District Tasikmalaya Regency). Jurnal Ilmu Ternak, $1(1), 1-6$.

Hivos. (2014a). Final Report Indonesia Domestic Biogas Programme May 2009 - December 2013. Jakarta

Hivos. (2014b). Interim Report Indonesia Domestic Biogas Programme January - June 2014. Jakarta

Ilskog, E. (2008). Indicators for assessment of rural electrificationAn approach for the. Energy Policy, 36, 2665-2673.

International Finance Corporation (IFC). (2011). Dairy Industry Development in Indonesia. Jakarta

Kabir, H., Yegbemey, R. N., \& Bauer, S. (2013). Factors determinant of biogas adoption in Bangladesh. Renewable and Sustainable Energy Reviews, 28, 881-889.

Kossmann, W., Pönitz, U., Habermehl, S., Hoerz, T., Krämer, P., Klingler, B. et al. (undated). Biogas Digest Volume I Biogas Basics. Eschborn: Information and Advisory Service on Appropriate Technology (ISAT) \& Gesellschaft für Technische Zusammenarbeit (GTZ).

Lam, J., \& Heegde, F. t. (2011). Domestic Biogas Compact Course: Technology and Mass-Dissemination Experiences from Asia. Oldenburg University of Oldenburg.

Laramee, J., \& Davis, J. (2013). Economic and environmental impacts of domestic bio-digesters: Evidence from Arusha, Tanzania. Energy for Sustainable Development, 17, 296-304.

Listyawati, R. N., Meidiana, C., \& Anggraeni, M. (2014). Evaluation of energy self-sufficient village by means of emergy indices. Procedia Environmental Sciences,20, 30 - 39.

Macias-Corral, M., Samani, Z., Hanson, A., Smith, G., Funk, P., Yu, H., et al. (2008). Anaerobic digestion of municipal solid waste and agricultural waste and the effect of co-digestion with dairy cow manure. Bioresource Technology, 8288-8293.

Marañón, E., Salter, A., Castrillón, L., Heaven, S., \& Fernández-Nava, Y. (2011). Reducing the environmental impact of methane emissions from dairy farms by anaerobic digestion of cattle waste. Waste Management, 31, 1745-1751.

Marquardt, J. (2014). A Struggle of Multi-level Governance: Promoting Renewable Energy in Indonesia. Energy Procedia 58, 87 - 94.

Massé, D. I., Talbot, G., \& Gilbert, Y. (2011). On Farm Biogas Production: a Method to Reduce GHG Emissions and Develop More Sustainable Livestock Operations. Animal Feed Science and Technology , 436- 445.

Moody, L. B., Burns, R. T., Bishop, G., Sell, S., \& Spajic, R. (2011). Using biochemical methane potential assays to aid in co-substrate selection for co-digestion. Applied Engineering in Agriculture, 433-439.

Mwakaje, A. G. (2008). Dairy farming and biogas use in Rungwe district, South-west Tanzania: A study of opportunities and constraints. Renewable and Sustainable Energy Reviews, 12, 2240-2252.

Nurmalina, R., \& Riesti, S. (2010). Analisis Biaya Manfaat Pengusahaan Sapi Perah Dan Pemanfaatan Limbah Untuk Menghasilkan Biogas Pada Kondisi Resiko (Studi Kasus : Kecamatan Cisarua dan Megamendung, Kabupaten Bogor Jawa Barat. Jurnal Pertanian, 17-34.

Oparaocha, S., \& Dutta, S. (2011). Gender and energy for sustainable development. Environmental Sustainability, 3, 265-271.

Parikesit, Takeuchi, K., Tsunekawa, A., \& Abdoellah, O. S. (2005). Resource analysis of small-scale dairy production system in an Indonesian village - a case study. Agriculture, Ecosystems and Environment,105, 541-554.
Pathak, H., Jain, N., Bhatia, A., Mohanty, S., \& Gupta, N. (2009). Global warming mitigation potential of biogas plants in India. Environ Monit Assess, 157, 407-418.

Prasetyo, A., \& Herawati, H. (2011). Pengaruh Kualitas Susu Terhadap Keuntungan Agribisnis Sapi Perah Skala Kecil di Jawa Tengah. Prosiding Semiloka Nasional "Dukungan Agro-Inovasi untuk Pemberdayaan Petani (pp. 840-845).

Purwono, B. S., Suyanta, \& Rahbini. (2013). Biogas digester as an alternative energy strategy in the marginal villages in Indonesia. Energy Procedia 32, $136-144$.

Putri, D., Saputro, R., \& Budiyono. (2012). Biogas Production from Cow Manure. Int. Journal of Renewable Energy Development 1 (2), 6164.

Rico, C., Diego, R., Valcarce, A., \& Rico, J. L. (2014). Biogas Production from Various Typical Organic Wastes Generated in the Region of Cantabria (Spain): Methane Yields and Co-Digestion Tests. Smart Grid and Renewable Energy , 128-136.

Rosyidi, S. A., Bole-Rentel, T., Lesmana, S. B., \& Ikhsan, J. (2014). Lessons Learnt from the Energy Needs Assessment carried out for the Biogas Program for Rural Development in Yogyakarta, Indonesia. Procedia Environmental Sciences, 20, 20 - 29.

Sayaka, B., \& Rivai, R. S. (2011). Enhancing Farmers' Access to Food Security and Energy Credit. Prosiding Seminar Pembangunan Pertanian dan Perdesaan (pp. 188-208).

Schnürer, A., \& Jarvis, Å. (2010). Microbiological Handbook for Biogas Plants. Malmö: Swedish Waste Management.

Scialabba, N. E.-H., \& Muller-Lindenlauf, M. (2010). Organic agriculture and climate change. Renewable Agriculture and Food Systems, 25(2), 158-169.

Sharma, S., \& Nema, B. P. (2013). Applicability of Biogas Technology in Rural Development and Green House Gas Mitigation. International Journal of ChemTech Research, 5(2), 747-752.

Singh, R., \& Setiawan, A. D. (2013). Biomass energy policies and strategies:Harvesting potential in India and Indonesia. Renewable and Sustainable Energy Reviews, 22, 332-345.

SNV. (2011). International Workshop on "Domestic biogas programmes in Asia: transformation towards commercial sectors and development of effective financing facilities". Bandung: SNV.

Sun, D., Bai, J., Qiu, H., \& Cai, Y. (2014). Impact of government subsidies on household biogas use in rural China. Energy Policy, 73, 748-756.

Surendra, K., Takara, D., Hashimoto, A. G., \& Khanal, S. K. (2014). Biogas as a sustainable energy source for developing countries: Opportunities and challenges. Renewable and Sustainable Energy Reviews, 31, 846-859.

Swastika, D. K. S. (2011). Membangun Kemandirian Dan Kedaulatan Pangan Untuk Mengentaskan Petani Dari Kemiskinan. Pengembangan Inovasi Pertanian, 4(2), 103-117.

The Japan Institute of Energy. (2008). Buku Panduan Biomassa Asia . Tokyo: The Japan Institute of Energy.

United Nations. (2007). Indicators of Sustainable Development: Guidelines and Methodologies. New York: United Nations.

Wahyudi, J. (2013). Identifikasi Faktor-faktor yang Mempengaruhi Pengembangan Biogas di Peternakan Sapi Perah. Pati.

Widodo, T. W., \& Hendriadi, A. (2005). Development of Biogas Processing for Small Scale Farm in Indonesia. Proceeding of International Seminar on Biogas Technology for Poverty Reduction and Sustainable Development, (pp. 1-7).

Widodo, T. W., Asari, A., Ana, N., \& Elita, R. (2009). Design And Development of Biogas Reactor For Farmer Group Scale. Indonesian Journal of Agriculture, 2(2), 121-128.

Widyastuti, F. R., Purwanto, \& Hadiyanto. (2013). Biogas Potential from the Treatment of Solid Waste of Dairy Cattle: Case Study at Bangka Botanical Garden Pangkalpinang. International Journal of Waste Resources, 3: 128.

Wilkinson, K. G. (2011). Review A comparison of the drivers influencing adoption of on-farm anaerobic digestion in Germany and Australia. Biomass and Bioenergy, 35, 1613-1622.

Zheng, Z., Liu, J., Yuan, X., Wang, X., Zhua, W., Yang, F., et al. (2015) Effect of dairy manure to switchgrass co-digestion ratio on methane production and the bacterial community in batch anaerobic digestion. Applied Energy, 249-257. 